\title{
Zamówienia publiczne na innowacje
}

\section{Public procurement of innovation}

Streszczenie. Autorka podejmuje problematykę zagadnienia zamówień publicznych na innowacje (PPI i PCP), przybliżając znaczenie tej instytucji prawnej, przedstawia i wyjaśnia ją przez wskazanie charakterystyki, zwracając uwagę na rolę, jaką spełniają w obrocie gospodarczym, oraz oczekiwania Unii Europejskiej związane z ich stosowaniem. Charakterystyka zamówień przedkomercyjnych (PCP), jak również zamówień w dziedzinie innowacji (PPI) przybliża każdą z nich, wskazując na funkcje i znaczenie. Zamówienia na innowacje to zmiany w podejściu zamówień publicznych do nabywanych towarów, usług i robót budowlanych z perspektywy nabywania produktów, usług zawierających w sobie najnowsze rozwiązania techniki czy też najnowsze technologie. To również zmiana postrzegania zamówień publicznych jako narzędzia do osiągania celów oraz zaspokajania zdefiniowanych potrzeb przez jednostki publiczne. Wyższa jakość realizowanych zadań ma stać się stymulatorem rozwoju gospodarki.

Słowa kluczowe: zamówienia publiczne; zamówienia innowacyjne; PCP; PPI. 


\begin{abstract}
The Author deals with public procurement of innovation (PPI and PCP) introducing the meaning of this legal institution, presenting and explaining it. This goals are achieved by indicating its characteristic features, as well as paying attention to the role they play in the economic turnover, and the expectations of the European Union related to the use of public procurement of innovation. The characteristics of pre-commercial procurement (PCP), as well as orders in the field of innovation (PPI) bring these institutions closer to each other. Innovative orders are changes in an approach to public procurement of regarding a purchase of goods, services and works from the perspective of purchasing products, or services which are incorporated the latest technical solutions or the latest technologies. It is also a change in the perception of public procurement as a tool to achieve goals, and meet defined needs by public entities.
\end{abstract}

Keywords: public procurement; innovative orders; PCP; PPI.

\title{
1. Wprowadzenie
}

Istnienie nowych technologii w życiu codziennym i w sferze funkcjonowania poszczególnych podmiotów, w tym jednostek sektora finansów publicznych, jest czymś powszechnym.

Obserwujemy systematyczne wprowadzanie zmian w sferze publicznej, które poprzez wykorzystanie różnego rodzaju nowinek technologicznych mają z jednej strony usprawnić realizowanie zadań przez administrację publiczną, z drugiej zaś uczynić ją bardziej przyjazną dla każdego obywatela. Obserwowany jest trend zmierzający do tego, aby świadczone usługi publiczne miały poziom porównywalny do usług świadczonych przez sektor prywatny. Można więc pokusić się o stwierdzenie, że administracja publiczna, wykorzystując istniejące na rynku rozwiązania techniczne i technologiczne, zmierza do podnoszenia jakości świadczonych przez siebie usług i realizowanych zadań.

Autorka podejmuje problematykę zagadnienia zamówień publicznych na innowacje, przybliżając ich znaczenie, przedstawia i wyjaśnia je przez wskazanie charakterystyki, zwracając uwagę na rolę, jaką spełniają w obrocie gospodarczym, oraz oczekiwania Unii Europejskiej związane $\mathrm{z}$ ich stosowaniem. 
Zamówienia na innowacje to zmiany w podejściu zamówień publicznych do nabywanych towarów, usług i robót budowlanych z perspektywy nabywania produktów, usług zawierających w sobie najnowsze rozwiązania techniki czy też najnowsze technologie. To również zmiana postrzegania zamówień publicznych jako narzędzia do osiągania celów oraz zaspokajania zdefiniowanych potrzeb przez jednostki publiczne.

Komisja Europejska w komunikacie dotyczącym „szeroko zakrojonej strategii innowacyjnej dla UE” ${ }^{1}$ podkreśla znaczenie zamówień publicznych dla wzmocnienia potencjału innowacyjnego UE przy jednoczesnej poprawie jakości i wydajności usług publicznych. W ramach przyjętych dokumentów określających strategie rozwoju UE podkreślano znaczenie rozwoju gospodarki oraz potrzebę zwiększenie nakładów na rozwój innowacyjnych produktów, usługi oraz robót budowlanych. Zmagania, z jakimi zmierza się sektor publiczny, w tym wynikającymi z potrzeb zmian np. w zakresie opieki zdrowotnej wynikających z potrzeby nabywania najnowszych urządzeń, leków itp., niesie ze sobą konieczność nabywania produktów i usług cechujących się innowacyjnością.

Komisja Europejska jako działanie priorytetowe uznała zmianę i unowocześnienie przepisów dotyczących zamówień publicznych w celu zapewnienia w tym zakresie zrównoważonej polityki, wspierającej zapotrzebowanie na towary, usługi i działania zgodne z zasadami ochrony środowiska, odpowiedzialne pod względem społecznym i innowacyjne ${ }^{2}$. Państwa członkowskie zostały zobowiązane do podjęcia działania na rzecz innowacji w ramach krajowych programów reform opartych na zin-

1 Komunikat Komisji do Rady, Parlamentu Europejskiego, Europejskiego Komitetu Gospodarczo-Społecznego i Komitetu Regionów, Wykorzystanie wiedzy w praktyce: szeroko zakrojona strategia innowacyjna dla UE, Komisja Europejska, COM(2006) 502, wersja ostateczna, Bruksela 2006, https://eur-lex.europa.eu/LexUriServ/Lex UriServ.do?uri=COM:2006:0502:FIN:PL:PDF (dostęp: 20.01.2020 r.).

2 Komunikat Komisji Europejskiej do Parlamentu Europejskiego, Rady, Europejskiego Komitetu Ekonomiczno-Społecznego i Komitetu Regionów, Akt o jednolitym rynku: Dwanaście dźwigni na rzecz pobudzenia wzrostu gospodarczego i wzmocnienia zaufania „wspólnie na rzecz nowego wzrostu gospodarczego”, Komisja Europejska, $\operatorname{KOM}(2011)$ 206, wersja ostateczna, Bruksela 2011, s. 22, https://eurlex.europa.eu/legal-content/PL/TXT/PDF/?uri=CELEX:52011DC0206\&from=PL (dostęp: 30.04.2020 r.). 
tegrowanych wytycznych nowej strategii lizbońskiej na rzecz wzrostu i zatrudnienia.

Sektor publiczny jest postrzegany przez Komisję Europejską jako ten, który ma napędzać innowacje od strony popytowej i zapewnić, by jakość i efektywność usług publicznych nie ulegała stagnacji w długim okresie. Zamówienia publiczne obejmujące swoim zakresem innowacyjne rozwiązania mogą przyczyniać się do lepszego zrozumienia i dostępu do rynku oraz bardziej efektywnego procesu decyzyjnego opartego na dowodach przy jednoczesnym umożliwieniu organom publicznym realizacji celów polityk oraz osiąganiu lepszego wykorzystania środków poprzez optymalne połączenie wyższej jakości, szybszej dostawy i/lub ograniczonych kosztów w całym cyklu życia. Stąd też, mówiąc o zamówieniach publicznych na innowacje, oczekuje się, iż będą one realizowały cele polityk jednocześnie wpływając na rozwój gospodarczy państw członkowskich UE.

Wytyczne ONZ dotyczące biznesu i praw człowieka jednoznacznie podkreślają rolę zamówień publicznych ${ }^{4}$ jako istotnego narzędzia będącego w rękach administracji publicznej i umożliwiającego kształtowanie odpowiedzialnych postaw wśród przedsiębiorców.

Zamiarem Unii Europejskiej jest zwiększenie efektywności wydatków publicznych, ułatwienie udziału małych i średnich przedsiębiorstw (MŚP) w zamówieniach publicznych, a także umożliwienie zamawiającym lepszego wykorzystania zamówień publicznych dla wsparcia wspólnych

3 Komunikat Komisji Europa 2020, Strategia na rzecz inteligentnego i zrównoważonego rozwoju sprzyjajq̨cego włączeniu społecznemu, Komisja Europejska, Kom(2020) 2020, wersja ostateczna, Bruksela 2010,

http://ec.europa.eu/eu2020/pdf/1_PL_ACT_part1_v1.pdf (dostęp: 20.01.2020 r.).

4 Wytyczna nr 6: „Państwa powinny promować poszanowanie praw człowieka przez przedsiębiorstwa, z którymi zawierają transakcje handlowe”, oraz komentarz do Wytycznej nr 6: „Państwa zawierają wiele różnorodnych transakcji handlowych z przedsiębiorstwami, także w drodze zamówień publicznych. To daje państwom (...) unikalne możliwości promowania świadomości i poszanowania praw człowieka wśród tych właśnie przedsiębiorstw, między innymi dzięki wprowadzeniu odpowiednich warunków do zawieranych umów, z uwzględnieniem odpowiednich zobowiązań państw wynikających z prawa krajowego i międzynarodowego"; Wytyczne dotyczq̨ce biznesu i praw człowieka. Wdrażanie Dokumentu Ramowego ONZ „Chronić, Szanować i Naprawiać”, Polski Instytut Praw Człowieka i Biznesu, 2014, s. 22. 
celów społecznych, wdrażania innowacyjnych rozwiązań oraz rozwiązań służących ochronie środowiska.

Zamówienia publiczne są uznawane za jedną ze sfer życia społecznogospodarczo-politycznego wpływającą na rozwój, będąc również narzędziem i przedmiotem zmian, które uwidaczniają rolę państwa w systemie nabywania towarów, usługi i robót budowlanych.

\section{Pojęcie innowacji}

Termin innowacja pochodzi od łacińskiego słowa innovare i oznacza „odnawiać" 5 .

W literaturze brak jednoznacznej definicji pojęcia innowacyjności, co nie przeszkadza w tworzeniu i publikacji opracowań prawniczych oraz ekonomicznych dotyczących innowacyjności. Niejednokrotnie pojęcie innowacji jest porównywane z pojęciem nowości, która może występować na trzech poziomach:

- $\quad$ nowość dla firmy (new to the firm),

- $\quad$ nowość dla rynku (new to the market),

- $\quad$ nowość w skali światowej (new to the world) ${ }^{6}$.

Nie należy jednak utożsamiać ze sobą tych dwóch pojęć. Głównym elementem innowacji odróżniającym go od nowości jest dyfuzja nowej wiedzy i technologii. Strategicznym punktem powyższego jest termin nowy. Integralną częścią definicji innowacji według Schumpetera jest pierwsze zastosowanie danego rozwiązania ${ }^{7}$.

Definicje innowacji powstające po II wojnie światowej można interpretować w szerokim bądź wąskim znaczeniu, od początkowego podkreślania ich aspektów technologicznych, po bardzo szerokie kategorie

\footnotetext{
5 https://encyklopedia.pwn.pl/haslo/innowacje;3914833.html (dostęp: 15.12 .2019 r.).

$6 \quad$ Innowacyjne zamówienia publiczne w Polsce - ekspertyza, Polska Agencja Rozwoju Przedsiębiorczości, Warszawa 2011, s. 15, https://www.uzp.gov.pl/_data/assets/pdf_file/0021/ 30684/Innowaycjne_zamowienia_publiczne_ekspertya_2011.pdf (dostęp: 20.01.2020 r.).

7 P. Niedzielski, K. Rychlik, Innowacje i kreatywność, Szczecin 2006, s. 19.
} 
obejmujące takie dziedziny jak życie społeczne i gospodarcze, technika czy przyroda ${ }^{8}$.

Odmiennie określił definicję innowacji Barnett, opierając się na założeniu, że jest ona każdą koncepcją, pomysłem, postawą, stanowiskiem lub rzeczą, która swą jakością wyróżnia się spośród wszystkich istniejących do chwili obecnej ${ }^{9}$.

Definicję innowacji zawarto w Oslo Manual ${ }^{10}$, według której innowacja to wdrożenie nowego lub znacząco udoskonalonego produktu (wyrobu lub usługi) lub procesu, nowej metody marketingowej lub nowej metody organizacyjnej w praktyce gospodarczej, organizacji miejsca pracy lub stosunkach z otoczeniem. Przyjęto w niej również, że minimalnym wymogiem zaistnienia innowacji jest to, aby produkt, proces, metoda marketingowa lub metoda organizacyjna były nowe (lub znacząco udoskonalone) dla firmy. Mogą to być produkty, procesy i metody, które dana firma opracowała jako pierwsza, oraz te, które zostały przyswojone od innych firm lub podmiotów.

Niezależnie od przyjętej definicji innowacji należy przyjąć, opierając się w dużej mierze na pewnej intuicyjności, że jest to proces, w wyniku którego dochodzi do wdrożenia na określonej płaszczyźnie nowych rozwiązań technicznych, technologicznych, marketingowych, produktowych itp.

Nauki ekonomiczne pojęcie innowacji łączą z wprowadzeniem nowych technologii i tworzeniem organizacji oraz instytucji. Działalność innowacyjna jest uważana za warunek rozwoju gospodarczego. Wdrożenie innowacji to również przełamywanie oporu społecznego, głównie w jego konserwatywnej części ${ }^{11}$.

8 M. Zastempowski, Uwarunkowania budowy potencjału innowacyjnego polskich małych i średnich przedsiębiorstw, Toruń 2010, s. 57-60.

9 P.F. Borowski, Przedsiębiorstwa XXI wieku, „Europejski Doradca Samorządowy” 2011, t. 17, nr 2, s. 8-13.

10 Oslo Manual: Guidelines for Collecting and Interpreting Innovation Data, OECD, Eurostat 2005, wydanie trzecie, https://www.oecd-ilibrary.org/docserver/9789264013100-en.pdf (dostęp: 15.12.2019 r.).

11 H. Nowicki, System zamówień publicznych jako regulacja prawna kreująca innowacyjność [w:] J. Niczyporuk, J. Sadowy, M. Urbanek (red.), Nowe podejście do zamówień publicznych - zamówienia publiczne jako instrument zwiększenia innowacyjności 
W literaturze wyróżniono kilka rodzajów innowacji, które występują również w sektorze usług publicznych, realizowanych poprzez procedury zamówień publicznych. W zależności od kryterium podziału możliwe jest wyodrębnienie następujących rodzajów innowacji:

1. innowacje w obrębie produktów (produktowe) - wg Podręcznika Oslo Manual (product innovation) to wprowadzenie wyrobu lub usługi, które są nowe lub znacząco udoskonalone w zakresie swoich cech lub zastosowań. Zalicza się tu znaczące udoskonalenia pod względem specyfikacji technicznych, komponentów i materiałów, wbudowanego oprogramowania, łatwości obsługi lub innych cech funkcjonalnych. Do innowacji produktowych zalicza się zarówno wprowadzenie nowych wyrobów i usług, jak i znaczące udoskonalenia istniejących wyrobów i usług w zakresie ich cech funkcjonalnych lub użytkowych. Innowacje produktowe w sektorze usług mogą polegać na wprowadzeniu znaczących udoskonaleń w sposobie świadczenia usług (na przykład na podniesieniu sprawności czy szybkości ich świadczenia), na dodaniu nowych funkcji lub cech do istniejących usług lub na wprowadzeniu całkowicie nowych usług ${ }^{12}$;

2. innowacje w obrębie procesów (procesowe) - wg Podręcznika Oslo Manual (process innovation) to wdrożenie nowej lub znacząco udoskonalonej metody produkcji lub dostawy. Do tej kategorii zalicza się znaczące zmiany $\mathrm{w}$ zakresie technologii, urządzeń oraz/lub oprogramowania ${ }^{13}$;

3. innowacje marketingowe - wg Podręcznika Oslo Manual (marketing innovation) to wdrożenie nowej metody marketingowej wiążącej się ze znaczącymi zmianami $\mathrm{w}$ projekcie/konstrukcji produktu lub w opakowaniu, dystrybucji, promocji lub strategii cenowej ${ }^{14}$;

gospodarki i zrównoważonego rozwoju. Doświadczenia polskie i zagraniczne, Warszawa 2011, s. 111.

12 Oslo Manual: Guidelines for Collecting..., s. 50-54.

13 Tamże.

14 Tamże. 
4. innowacje organizacyjne - wg Podręcznika Oslo Manual (organisational innovation) to wdrożenie nowej metody organizacyjnej w przyjętych przez firmę zasadach działania, w organizacji miejsca pracy lub w stosunkach z otoczeniem ${ }^{15}$;

5. innowacje oryginalne (kreatywne) - są samodzielnymi wytworami pracy jednostki, zespołu lub przedsiębiorstwa;

6. innowacje imitujące - polegają na naśladownictwie i odtwarzaniu oryginalnych zmian, które w danym czasie i miejscu przynoszą określone korzyści;

7. innowacje twarde - których przejawem są nowe maszyny i urządzenia;

8. innowacje miękkie - które mają postać np. nowego systemu organizacji, usprawnienia $\mathrm{w}$ systemie szkolenia załogi itp. Mają zastosowanie głównie do nauk organizacji i zarządzania, ekonomiki i nauk społecznych ${ }^{16}$.

W art. 2 ust. 1 pkt 22 dyrektywy 2014/24/UE ${ }^{17}$ zawarta została definicja innowacji, zgodnie z którą innowacje oznaczają wdrażanie nowego lub znacznie udoskonalonego produktu, usługi lub procesu, w tym między innymi procesów produkcji, budowy lub konstrukcji, nowej metody marketingowej lub nowej metody organizacyjnej w działalności przedsiębiorczej, organizowaniu pracy lub relacjach zewnętrznych, m.in. po to, by pomóc podjąć wyzwania społeczne lub wspierać strategię „Europa 2020” na rzecz inteligentnego i zrównoważonego rozwoju sprzyjającego włączeniu społecznemu. Innowacyjność jest to, jak słusznie wskazuje H. Nowicki, inny, dodatkowy cel pozazakupowy osiągany w ramach wydatkowania środków w systemie zamówień publicznych ${ }^{18}$.

\footnotetext{
Tamże.

Innowacyjne zamówienia..., s. 15-20.

17 Dyrektywa Parlamentu Europejskiego i Rady 2014/24/UE z dnia 26 lutego 2014 r. w sprawie zamówień publicznych, uchylająca dyrektywę 2004/18/WE, Dz.Urz. UE L 2014 Nr 94, s. 65.

18 H. Nowicki, Innowacyjność zamówień publicznych [w:] M. Stręciwilk, A. Dobaczewska (red.) Potrzeby i kierunki zmian w Prawie zamówień publicznych, Warszawa 2018, s. 199.
} 
W orzecznictwie podnosi się, iż polski ustawodawca implementował wskazaną w dyrektywie definicję pojęcia innowacyjności w ograniczonym zakresie, odwołując się do niego tylko i wyłącznie w przepisach regulujących tryb partnerstwa innowacyjnego, zmieniając jednakże w stosunku do prawa UE przedmiot partnerstwa, odnosząc go w sposób bardzo szeroki do nowych lub znacznie udoskonalonych produktów, usług lub procesów ${ }^{19}$.

Brak ustawowej definicji innowacyjności zamieszczonej w ustawie prawo zamówień publicznych oceniany jest w doktrynie negatywnie, podnosi się przy tym, iż pojawia się brak pewności co do zakresu znaczeniowego tegoż pojęcia. Ponadto poprzez użycie go tylko dla trybu partnerstwa innowacyjnego ustawodawca sugeruje, iż jakoby tylko w tym trybie można było nabywać towary i usługi innowacyjne ${ }^{20}$.

\section{Pojęcie zamówień publicznych na innowację}

Stosowanie zamówień na usługi badawczo-rozwojowe promowane było przez Parlament Europejski, Radę Europejską i Komisję Europejską od wielu lat. Podstawowym założeniem jest twierdzenie, iż siłą napędową innowacji w gospodarce poza przedsiębiorcami są również jednostki sektora finansów publicznych, które wydatkując środki na zaspokojenie ich potrzeb, mogą korzystać z zamówień innowacyjnych.

W rezolucji Parlamentu Europejskiego z czerwca 2007 r. dotyczącej transpozycji i wdrożenia prawodawstwa w zakresie zamówień publicznych $^{21}$ zachęcono do szerszego wykorzystania w UE zamówień na innowacje w tym zamówień przedkomercyjnych.

Komisja Europejska w grudniu 2007 roku wydała Komunikat do Parlamentu Europejskiego, Rady Europejskiej Komitetu Ekonomiczno-

19 Tamże, s. 200.

20 Tamże.

21 Rezolucja Parlamentu Europejskiego z dnia 20 czerwca 2007 r. w sprawie szczegółowych problemów związanych z transpozycją i stosowaniem prawodawstwa dotyczącego zamówień publicznych oraz związków tego prawodawstwa z agendą lizbońską (2006/2084(INI)), Dz.Urz. UE C 146E/227, Tom 51 z dnia 12 czerwca 2008 r. 
-Społecznego i Komitetu Regionów, Zamówienia przedkomercyjne: wspieranie innowacyjności w celu zapewnienia trwałości i wysokiej jakości usług publicznych $w$ Europie $\{\text { SEC(2007) 1668 }\}^{22}$, podkreślając w nim, iż możliwości związane z zamówieniami przedkomercyjnymi (PCP) nie są w Europie wykorzystywane. W treści komunikatu, tłumacząc rolę i znaczenie zamówień przedkomercyjnych, wezwano Europę do korzystania z tej instytucji, widząc w zamówieniach PCP drogę do rozwoju innowacji.

W Rezolucji w sprawie zamówień przedkomercyjnych: wspieranie innowacyjności w celu zapewnienia trwałości i wysokiej jakości usług publicznych w Europie ${ }^{23}$ Parlament Europejski podnosił, iż zamówienia przedkomercyjne stanowią niedostatecznie wykorzystywaną siłę napędową dla wzrostu sterowanego przez innowacje w UE, cechując się znacznym potencjałem w zakresie realizacji łatwo dostępnych usług publicznych wysokiej jakości, np. opieki zdrowotnej czy transportu. Wskazywano, że zamówienia przedkomercyjne można stosować w ramach istniejących ram prawnych określonych przez obowiązujące wówczas dyrektywy 2004/17/WE oraz 2004/18/WE ${ }^{24}$. Apelowano do państw członkowskich, żeby te zbadały ustawodawstwo krajowe, aby sprawdzić, czy władze publiczne nie są ograniczane w dokonywaniu zamówień przedkomercyjnych przez nieistniejące, nieprawidłowe czy też niepotrzebnie skomplikowane przepisy transpozycyjne dotyczące właściwych odstępstw bądź też zbędnie rozbudowane krajowe wymogi w zakresie przetargów czy modele składania zamówień.

22 https://eur-lex.europa.eu/LexUriServ/LexUriServ.do?uri=COM:2007:0799:FIN: PL:PDF (dostęp: 27.04.2020 r.).

23 Rezolucja Parlamentu Europejskiego z dnia 3 lutego 2009 r. w sprawie zamówień przedkomercyjnych: wspieranie innowacyjności w celu zapewnienia trwałości i wysokiej jakości usług publicznych w Europie (2008/2139(INI)), Dz.Urz. UE C 67E/10, Tom 53 z dnia 18 marca $2010 \mathrm{r}$. Dyrektywa 2004/17/WE Parlamentu Europejskiego i Rady z dnia 31 marca 2004 r. koordynująca procedury udzielania zamówień przez podmioty działające w sektorach gospodarki wodnej, energetyki, transportu i usług pocztowych, Dz.Urz. WE L 2004 Nr 134, s. 1 (nieobowiązująca), dyrektywa 2004/18/WE Parlamentu Europejskiego i Rady z dnia 31 marca 2004 r. w sprawie koordynacji procedur udzielania zamówień publicznych na roboty budowlane, dostawy i usługi, Dz.Urz. WE L 2004 Nr 134, s. 114 (nieobowiązująca). 
Rada Europejska w Konkluzji posiedzenia Rady UE ds. Konkurencyjności 4 grudnia 2006 r. $^{25}$ zwróciła się do Komisji Europejskiej o opracowanie wytycznych $\mathrm{w}$ sprawie wykorzystania przepisów UE w zakresie zamówień publicznych do stymulowania innowacyjności. W Konkluzji z 4 lutego 2011 r. $^{26}$, Konkluzji z 24-25 października 2013 r. $^{27}$ Rada zachęcała państwa członkowskie do wykorzystywania zamówień w polityce innowacyjnej, podnosząc, iż innowacje w poszczególnych dziedzinach życia sprzyjają trwałemu wzrostowi gospodarczemu, zaś zwiększenie wydajności systemów państw członkowskich w zakresie nauki i innowacji powinno być wspólnym celem Komisji Europejskiej i poszczególnych członków UE.

27 stycznia 2011 r. Komisja Europejska opublikowała Zieloną Księgę na temat konieczności modernizacji polityk UE dotyczących zamówień publicznych $^{28}$. Był to krok zmierzający do wdrożenia zmian legislacyjnych i rekomendacji do wdrożenia zamówień na innowacje we wszystkich krajach Unii.

Przepisy obowiązujące na terenie Rzeczpospolitej Polskiej nie kształtują odmiennego systemu prawnego w zakresie nabywania przez jednostki sektora finansów publicznych innowacyjnych towarów, usług czy też robót budowlanych. Opracowując dokumentację niezbędną dla danego postępowania opartego na ustawie Prawo zamówień publicznych $^{29}$, dotyczącą innowacyjnych rozwiązań, nie należy szukać odmiennej podstawy prawnej dla podejmowanych czynności.

Unia Europejska promuje zamówienia publiczne na innowacje zarówno poprzez zamówienia przedkomercyjne (PCP) - które mogą być

25 Podane za: https://eur-lex.europa.eu/LexUriServ/LexUriServ.do?uri=COM:2007:0799: FIN:PL:PDF (dostęp: 27.04.2020 r.).

26 http://data.consilium.europa.eu/doc/document/ST-2-2011-INIT/pl/pdf (dostęp: 27.04.2020 r.), s. $6-10$.

27 https://www.consilium.europa.eu/uedocs/cms_data/docs/pressdata/PL/ec/139205.pdf (dostęp: 27.04.2020 r.), s. 6-7.

28 Zielona księga $w$ sprawie modernizacji polityki UE $w$ dziedzinie zamówień publicznych. W kierunku zwiększenia skuteczności europejskiego rynku zamówień, Komisja Europejska, $\operatorname{KOM(2011)~15,~wersja~ostateczna,~Bruksela~} 2011$.

29 Ustawa z dnia 29 stycznia 2004 r. Prawo zamówień publicznych (Dz.U. z 2019 r., poz. 1843 ze zm.). 
wykorzystane, gdy nie ma jeszcze rozwiązań bliskich rynkowi i potrzebne są nowe badania i rozwój - jak i poprzez zamówienia publiczne na innowacyjne rozwiązania (PPI), których celem jest nabywanie istniejących innowacji, które jeszcze nie osiągnęły pełnej komercjalizacji, ale nie wymagają nowych działań $\mathrm{B}+\mathrm{R}^{30}$.

Innowacja w zamówieniach publicznych zajmuje się rozpoznaniem nowych technologii zdolnych do odpowiedzi na wyzwania społeczne poprzez rozwiązania, które albo już istnieją na niewielką skalę na rynku (Zamówienia Publiczne na Innowacyjne Rozwiązania, PPI), albo mają być opracowane od zera począwszy od fazy B+R (Zamówienia Przedkomercyjne, PCP). Mamy więc do czynienia z dwojakim postrzeganiem innowacyjnych zamówień.

Pojęcie zamówienie publiczne na innowacje charakteryzowane jest przez:

1. innowacyjny przedmiot zamówienia,

2. trudność w sprecyzowaniu przedmiotu zamówienia na etapie ogłoszenia o zamówieniu,

3. zastosowanie procedury umożliwiającej sprecyzowanie przedmiotu zamówienia podczas postępowania,

4. większą otwartość w określaniu przedmiotu zamówienia - sektor prywatny uczestniczy w określaniu przedmiotu zamówienia (np. w odniesieniu do możliwości technicznych),

5. MEAT (Most Economically Advantageous Tender - oferta najkorzystniejsza ekonomicznie) - kryteria wyboru najkorzystniejszej oferty, dla których cena zakupu nie jest podstawowym i najważniejszym elementem,

6. większe zaangażowanie ekspertów merytorycznych,

7. większe ryzyko związane z zamówieniem (niepewność sukcesu),

8. istotną rolę przyzwolenia politycznego na innowacyjność.

A. Borowiec wskazuje, iż innowacyjne dostawy to dostawy innowacji materialnej, czyli czegoś nowego nieznanego, bądź innowacji niematerialnej, czyli dostawa praw $\mathrm{z}$ dziedziny autorskich praw

30 Zob.: https://ec.europa.eu/digital-single-market/en/innovation-procurement (dostęp: 19.01.2020 r.). 
majątkowych lub praw z dziedziny własności przemysłowej, które nie były do tej pory wykorzystywane ${ }^{31}$.

Zamówienia publiczne na innowacje ${ }^{32}$ oznaczają zamówienia publiczne, których przedmiot ma innowacyjny charakter. Komisja Europejska w opublikowanym w październiku 2017 r. Projekcie Wytycznych

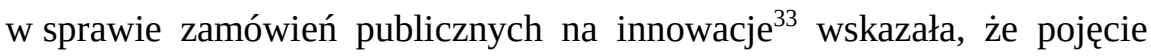
zamówień publicznych na innowacje odnosi się do każdego procesu, który obejmuje zakup procesu innowacji lub zakup wyników procesu innowacji.

Obok pojęcia zamówień publicznych na innowacje w literaturze, ale i dokumentach, ekspertyzach powszechnie publikowanych, występuje pojęcie innowacyjnych zamówień publicznych, które wydaje się mieć dużo szersze znaczenie. Pojęcie innowacyjnych zamówień publicznych zawiera w sobie poza innowacyjnym przedmiotem również stosowanie innowacyjnych rozwiązań w samym procesie udzielania zamówienia, w tym chociażby korzystanie z elektronicznych katalogów ${ }^{34}$. A więc jeśli mówimy o zamówieniach publicznych na innowacje, kierujemy naszą uwagę na efekt, który musi spełniać cechy charakterystyczne dla produktu, usługi innowacyjnej. Jeśli zaś mówimy o innowacyjnych zamówieniach zakresem swojego zainteresowania poza innowacyjnych przedmiotem, obejmujemy również sposób prowadzenia postępowania o udzielenie zamówienia publicznego.

Określenie innowacyjnych zamówień znajduje się w opinii przygotowanej na zlecenie Ministerstwa Gospodarki przez Grupę Doradczą Sienna Sp. z o.o., skupiając się na przedmiocie zamówienia, wskazując iż:

31 A. Borowiec, Zamówienia publiczne jako instrument kreowania popytu na innowacje, Poznań 2013, s. 50-52.

32 J. Pożarowska, Zamówienia publiczne na innowacje - czy $(m)$ sq? [w:] M. Stręciwilk, A. Dobaczewska (red.), Potrzeby i kierunki zmian w Prawie zamówień publicznych, Warszawa 2018, s. 182.

33 Consultation document on Guidance on Public Procurement of Innovation. Draft version to be submitted to the targeted consultation, Komisja Europejska 2017, https://ec.europa.eu/docsroom/documents/25724, s.5, (dostęp: 05.12.2019 r.).

34 J. Pożarowska, Zamówienia publiczne na innowacje..., s. 185. 
1. innowacyjną dostawą może być:

a) innowacja produktowa (materialna) w postaci:

- dostawy zupełnie nowego, nieznanego na terenie kraju lub w danej instytucji zamawiającej produktu (towaru), w tym także maszyny, urządzenia, oprogramowania lub systemu;

- dostawy produktu znanego już, jednak ulepszonego w takim stopniu, iż z tego powodu cały produkt należy uznać za innowacyjny;

b) innowacja niematerialna w postaci:

- dostawy prawa z dziedziny autorskich praw majątkowych, dotyczącej przeniesienia autorskich praw majątkowych do utworu lub prawa do korzystania z utworu, wnoszącego do praktyki elementy nowości;

- dostawy prawa z dziedziny własności przemysłowej, dotychczas niewykorzystywanego na terenie kraju lub w danej instytucji ${ }^{35}$.

2. innowacyjną usługą będzie udzielenie zamówienia publicznego na usługi, których celem jest opracowanie innowacyjnych procesów, metod, organizacji. Przykładem mogą być zamówienia na prowadzenie badań, analiz czy wypracowanie pewnych nowatorskich w danej dziedzinie rozwiązań. Innowacyjne będzie także zamówienie zakładające ulepszenie rozwiązań już istniejących. Innowacje w zakresie usług można zaliczyć do innowacji organizacyjnej, marketingowej lub procesowej, ale już nie do kategorii innowacji produktowej. Jako przykład usług, których przedmiotem nie są badania naukowe i prace rozwojowe, a które niewątpliwie są zamówieniem o charakterze innowacyjnym, podaje się opracowanie oprogramowania wnoszącego nowy wymiar działania danej instytucji, wykonanie wdrożeń systemów organizacji itp., które będą posiadać nowy lub znacząco ulepszony charakter od rozwiązań dotychczas stosowanych $^{36}$.

35 Tworzenie warunków dla zamówień publicznych sprzyjajq̨cych innowacjom, ekspertyza przygotowana przez Grupę Doradczą Sienna Sp. z o.o., Warszawa 2007, s. 17.

36 Tamże, s. 21. 
3. innowacyjną robotą budowlaną może być robota budowlana polegająca na:
a) innowacyjności projektu budowlanego w robotach budowlanych typu zaprojektuj + wybuduj;
b) innowacyjności zastosowanych podczas budowy technologii;
c) innowacyjności użytych do budowy materiałów lub surowców;
d) innowacyjności procesu inwestycyjnego;
e) innowacyjności użytych narzędzi informatycznych wspomagających prowadzenie procesu inwestycyjnego;
f) innowacyjności procesu kontroli wykonywanych robót;
g) innowacyjności zastosowanych rozwiązań z dziedziny ochrony środowiska.
Innowacja w robotach budowlanych będzie miała zazwyczaj charakter innowacji procesowej (technologicznej) lub organizacyjnej. W zamówieniach publicznych wyróżnić można także w robotach budowlanych innowacje produktowe w sytuacji, gdy do wykonania robót niezbędne będzie zastosowanie innowacyjnych materiałów lub urządzeń ${ }^{37}$.

Pojęcie zamówień na innowacje, jak zostało to powyżej przedstawione, jest dość pojemne, gdyż mieści w sobie nowy produkt, usługę czy robotę budowlaną oraz nowatorskie rozwiązania z określonej dziedziny życia.

\section{Zamówienia przedkomercyjne (PCP)}

Zamówienia przedkomercyjne, określane skrótem PCP, dotyczą zakupu usług badawczo-rozwojowych. Są one wykorzystywane w sytuacji, gdy nie ma możliwości rozwiązania określonej potrzeby zamawiającego za pomocą produktów dostępnych na rynku. Podstawowym założeniem zamówień przedkomercyjnych jest podział ryzyka pomiędzy zamawiającego i dostawcę, który ponosi część kosztów prac badawczych w zamian za utrzymanie praw do rezultatów swoich badań. Do każdej fazy zamówień przedkomercyjnych zapraszanych jest jednocześnie kilku przedsiębiorców, którzy niezależnie od siebie pracują nad rozwiązaniem problemu

37 Tamże. 
zamawiającego. Następnie mamy fazę procedury udzielenia zamówienia publicznego na realizację rozwiązania, które najpełniej zaspokoi oczekiwania podmiotu publicznego ${ }^{38}$.

Zamówienia PCP nie mają za cel nabycie istniejącego produktu czy usługi. Ich podstawowym zadaniem jest nabywanie usług B+R od wykonawcy w celu rozwiązywania wyzwań społeczno-gospodarczych w interesie publicznym, dla których nie ma gotowego rozwiązania.

Ponieważ zamówienia PCP nie są związane z zamówieniami już istniejącego produktu lub usługi, niezbędnym etapem zamówienia jest faza $\mathrm{B}+\mathrm{R}, \mathrm{z}$ badaniem i projektowaniem możliwych alternatywnych i konkurencyjnych rozwiązań, aż po prototypowanie oraz rozwój ograniczonej ilości produktów uznawanych za najlepszy możliwy rezultat. W związku z tym zamówienia PCP charakteryzują się podziałem ryzyka i korzyści zgodnego z warunkami rynkowymi, konkurencyjnym rozwojem w fazach oraz rozdziałem pomiędzy $\mathrm{B}+\mathrm{R}$ oraz finalną komercjalizacją produktów końcowych.

W praktyce zamówienia PCP rozpoczynają się rozpoznaniem potrzeb zebranych przez instytucję zamawiającą od użytkowników końcowych, która następnie ogłasza zaproszenie do składania ofert przetargowych wykonawcom konkurującym o udzielenie zamówienia w ramach PCP. Instytucja zamawiająca ocenia oferty i może udzielić zamówienia lub kilku zamówień dostawcy/dostawcom, który rozpocznie projektowanie i badanie wykonalności projektu przedstawionego w ofercie. Kolejnym etapem jest zbudowanie prototypu, aby w dalszym działaniu wytwarzać określoną ilość produktów lub usług.

Za zamówienie przedkomercyjne uznaje się udzielanie zamówień na usługi badawczo-rozwojowe inne niż usługi, z których korzyści przypadają wyłącznie instytucji zamawiającej, dla potrzeb jej własnej działalności, pod warunkiem, że całość wynagrodzenia za świadczoną usługę wypłaca instytucja zamawiająca i wynagrodzenie to nie stanowi pomocy publicznej ${ }^{39}$.

38 S. Sawin, W. Bereszko, Innowacyjne i przedkomercyjne zamówienia publiczne, Warszawa 2012, s. 10 i n.

39 Komunikat Komisji do Parlamentu Europejskiego, Rady, Europejskiego Komitetu Ekonomiczno-Społecznego i Komitetu Regionów, Zamówienia przedkomercyjne: 
Jak słusznie zauważa R. Cieślak, w zamówieniach PCP podmiot publiczny (zamawiający) przyjmuje rolę partnera współtworzącego ostateczny kształt innowacyjnego produktu lub usługi będącej przedmiotem zamówienia. Jego funkcja nie sprowadza się wyłącznie do roli klienta, nabywcy określonego dobra, jak dzieje się to w klasycznych zamówieniach publicznych. Podmiot publiczny bierze udział we wszystkich działaniach wspólnie z dostawcami na poszczególnych etapach realizacji zamówienia, współdzieląc ryzyko związane z opracowaniem innowacji i jej wdrożeniem. Do momentu uzyskania przedkomercyjnego rozwiązania przyjmuje na siebie rolę finansującego (lub współfinansującego) i staje się pierwszym klientem wytworzonej innowacji, która następnie komercjalizowana jest na rynku ${ }^{40}$.

Oddzielając zamówienia publiczne od komercyjnego wprowadzania produktów, zamówienia PCP koncentrują się na nabywaniu usług B+R wymagających znacznych ilości badań i inwestycji rozwojowych, które nie byłyby wykonane przez sektor prywatny bez wsparcia finansowego ze strony sektora publicznego, tym samym bez doprowadzenia do jednostronnej pomocy państwa dla branży. Do zamówień PCP można podejść zarówno z punktu widzenia krajowego/regionalnego/lokalnego, jak i w celu osiągnięcia ponadnarodowej współpracy. Różnica polega głównie na kompleksowości zamówień, liczbie zaangażowanych podmiotów i podstawach prawnych (np. w przypadku transgranicznych PCP musi zostać wybrana krajowa legislacja, aby odnieść się do wszystkich kroków procesu zamówień).

W Europie można znaleźć przykłady stosowania zamówień PCP, np. projekt realizowany na szczeblu lokalnym (miast), który miał na celu stworzenie i zoptymalizowanie systemów inteligentnych do ładowania pojazdów elektrycznych. Region Piemontu (Włochy) wykorzystał zamówienia PCP w celu przeprowadzenia zamówienia w zakresie usług $\mathrm{B}+\mathrm{R}$,

wspieranie innowacyjności w celu zapewnia trwałości i wysokiej jakości usług publicznych w Europie \{SEC(2007)1668\}, Komisja Europejska, KOM(2007) 799, wersja ostateczna, Bruksela 2007.

40 Szerzej: R. Cieślak, Przedkomercyjne zamówienia publiczne szansq na rozwój polskich regionów, „Gazeta Samorządu i Administracji” 2010, nr 13/14, www.gsia.infor.pl (dostęp: 10.12.2019 r.). 
w tym sprawdzenie poprawności i testowanie, aby uzyskać elementy prototypowe do stworzenia rozwiązań innowacyjnych w zakresie sieci inteligentnych, co umożliwi Regionowi Piemontu zoptymalizowanie infrastruktur oraz upowszechnienie systemów ładowania pojazdów elektrycznych, a także sieci inteligentnych zarządzanych poprzez zaangażowanie wszystkich partnerów (dostawa energii, produkcja, zużycie energii) ${ }^{41}$.

Podobnym projektem w zakresie zamówień PCP w mobilności jest MOBILE (Portugalia) ${ }^{42}$.

Przykładem zamówień PCP jest działanie konsorcjum instytucji badawczych oraz organizacji sektora publicznego z siedzibą w Danii, Finlandii, Szwecji oraz Wielkiej Brytanii, którego podstawowym celem jest wyszukiwanie i udostępnianie nowych technologii, aby pomagać osobom starszym z niepełnosprawnością fizyczną lub poznawczą. Zajmowało się ono zamówieniami przedkomercyjnymi (PCP) stosowanymi jako sposób ukierunkowania rozwoju rozwiązań w odniesieniu do konkretnych potrzeb społecznych ${ }^{43}$.

Zamówienia PCP mają na celu ukierunkowanie badań i rozwoju rozwiązań innowacyjnych na konkretne potrzeby sektora publicznego. W ramach prowadzonej procedury porównują i weryfikują podejścia alternatywnych rozwiązań od różnych dostawców funkcjonujących na rynku, a deklarujących chęć wzięcia udziału w zamówieniu, przed zaangażowaniem się w zamówienie na dużą skalę produktów wprowadzanych na rynek. W celu zapewnienia, aby podział ryzyka i korzyści został dokonany zgodnie $\mathrm{z}$ warunkami rynkowymi, dowolna korzyść $\mathrm{B}+\mathrm{R}$ dzielona przez nabywcę publicznego $\mathrm{z}$ firmą uczestniczącą $\mathrm{w}$ zamówieniach przedkomercyjnych powinna być równoważona przez firmę względem nabywcy publicznego po cenie rynkowej.

41 Projekt Inteligenta Sieć w Piemoncie we Włoszech, http://www.regione.piemonte.it/bandipiemonte/appl/dettaglio_bando_front.php?id_ban do=298 (dostęp: 10.12.2019 r.).

42 Więcej na temat tego projektu można znaleźć w publikacji: Policy Recommendations for advancing Pre-Commercial Procurement in Europe (Rekomendacje Polityki w zakresie rozwijania Zamówień Przedkomercyjnych w Europie), 2012, https://vbn.aau.dk/ws/files/72514419/PreCo_WP4_Policy_Recommendations_Final_2 012.pdf (dostęp: 20.01.2020 r.).

43 Projekt SILVER, http://www.silverpcp.eu/ (dostęp: 10.01.2020 r.). 
Ustawa prawo zamówień publicznych nie reguluje zamówień przedkomercyjnych jako odrębnej procedury ze względu na fakt, iż jest to nabycie usługi badawczo-rozwojowej, która na podstawie art. 4 ust. 3 lit. e ustawy Prawo zamówień publicznych podlega wyłączeniu. Do zamówień przedkomercyjnych nie stosuje się reżimu ustawy ani dyrektyw z zakresu zamówień publicznych, co pozwala na swobodę prowadzenia PCP w zakresie współpracy $\mathrm{z}$ wykonawcami biorącymi $\mathrm{w}$ nim udział, z zachowaniem przestrzegania podstawowych zasad traktowych, takich jak np. zapewnienie konkurencji, transparentność czy równe traktowa$n^{44}{ }^{44}$. Jak wskazuje P. Nowicki, zamówienia PCP są metodą inwestowania w sektor badań i rozwoju ${ }^{45}$, nie zaś procedurą udzielania zamówienia publicznego.

W doktrynie można spotkać się poglądem, iż zamówień przedkomercyjnych nie należy zaliczać do instytucji zamówień publicznych na innowacje ze względu na to, iż zamówienia publiczne na innowacje opierają się na procedurze określonej przez właściwe przepisy z zakresu zamówień publicznych, którego przedmiotem jest innowacyjne rozwiązanie, zamówienie przedkomercyjne stanowi zakup usług $\mathrm{B}+\mathrm{R}$ poza ustawą, na podstawie przewidzianego przez ustawę wyłączenia ${ }^{46}$.

\section{Zamówienia publiczne w dziedzinie innowacji (PPI)}

Zamówienia PPI są podejściem do zamówień publicznych, w których instytucje zamawiające działają jako klienci pierwotni na innowacyjne towary, roboty budowlane lub usługi, które są bliskie rynkowi, lub takie, które są już dostępne, ale na niewielką skalę, w tym są to rozwiązania oparte na istniejących technologiach wykorzystywanych w sposób innowacyjny.

\footnotetext{
44 J. Pożarowska, Zamówienia publiczne na innowacje..., s. 186.

45 P. Nowicki, Aksjologia prawa zamówień publicznych. Pomiędzy efektywnościq ekonomicznq a instrumentalizacja, Toruń 2019, s. 249.

46 J. Pożarowska, Zamówienia publiczne na innowacje..., s. 187.
} 
Zamówienia PPI stosowane są w przypadku nabywania istniejących nowych technologii, które nie wymagają prowadzenia badań i procesu wdrażania na rynku, a więc rozwiązania są już na rynku w małej skali, ale nie spełniają wymagań sektora publicznego na szeroką skalę. Sektor publiczny działa jak klient, który staje się pierwszym nabywcą dla innowacyjnych produktów i usług, które są nowo wchodzącymi na rynek, nie będąc jeszcze powszechnie dostępne na rynku. Czyli w praktyce nie mamy do czynienia z tworzeniem określonego rozwiązania, które będzie dopiero badane, testowane, a z towarem, usługą czy też robotą budowlaną istniejącą na rynku. Ryzyko i koszty związane z powstaniem produktu czy też usługi oraz jego wdrożeniem na rynek poniósł przedsiębiorca. Nabycie ich przez jednostki sektora finansów publicznych przyspieszy ich dostęp do rynku.

W praktyce zamawiający w ramach zamówień PPI ogłaszają z wyprzedzeniem swój zamiar kupna znacznej ilości rozwiązań innowacyjnych, aby pobudzić przemysł do dostarczenia na rynek rozwiązań o pożądanych wskaźnikach jakości/ceny w danym okresie.

Zamawiający poprzez formułowanie opisu przedmiotu zamówienia czy kryteriów oceny ofert posiada uprawnienie do kształtowania i preferowania innowacji. Stosowanie specyfikacji technicznych sprzyjających innowacjom bądź też kształtowanie kryteriów oceny i udzielanie zamówień oraz stały nadzór nad realizacją zamówienia, włączając nawet bodźce oparte o osiągane wyniki, są sposobem na osiąganie celu, jakim jest nabywanie produktów, usług bądź robót budowlanych wykorzystujących najnowsze osiągnięcia techniki, niestosowane na szeroką skalę bądź też projektowane i tworzone pod zapotrzebowanie zamawiającego.

Ustawodawca nie określa zamówień PPI, nie wskazuje ich jako nowego trybu, który jest podstawą do dokonania nabycia produktów innowacyjnych. Zamówienia PPI są metodą opierającą się na obowiązujących przepisach ustawy prawo zamówień publicznych pozwalającą osiągać cel, jakim jest nabywanie produktów, usług i robót innowacyjnych. Świadomy zamawiający, określając swoje potrzeby i efekt, jaki ma być osiągnięty z wykorzystaniem innowacyjnych rozwiązań, przygotowuje i prowadzi 
postępowanie w oparciu o obowiązujące przepisy prawa zamówień publicznych $^{47}$.

\section{Partnerstwo innowacyjne}

Partnerstwo innowacyjne jest trybem udzielenia zamówienia publicznego uregulowanym postanowieniami ustawy Prawo zamówień publicznych, w którym w odpowiedzi na publiczne ogłoszenie o zamówieniu zamawiający zaprasza wykonawców dopuszczonych do udziału w postępowaniu do składania ofert wstępnych, prowadzi z nimi negocjacje, a następnie zaprasza do składania ofert na opracowanie innowacyjnego produktu, usług lub robót budowlanych niedostępnych na rynku oraz sprzedaż tych produktów, usług lub robót budowlanych (art. 73a ustawy Prawo zamówień publicznych).

Tryb ten wprowadzony został do dyrektywy Parlamentu Europejskiego i Rady 2014/24/UE z 26 lutego 2014 r. w sprawie zamówień publicznych (klasycznej, art. 31) i dyrektywy 2014/25/UE (sektorowej, art. 47), a następnie implementowany do polskiego systemu prawnego na mocy ustawy z 22 czerwca 2016 r. o zmianie ustawy - Prawo zamówień publicznych oraz niektórych innych ustaw w art. 73a-73h.

Celem partnerstwa innowacyjnego jest opracowanie, a następnie nabycie innowacyjnego produktu, usługi lub robót budowlanych, pod warunkiem, że odpowiadają one poziomom wydajności i maksymalnym kosztom uzgodnionym między zamawiającym a uczestnikami postępowania. Wybór tego trybu wymaga od zamawiającego poprzedzenia szczegółowej analizy rynku w celu weryfikacji, czy istnieje rozwiązanie, które spełniałoby oczekiwania zamawiającego, czy też istnieje potrzeba stworzenia nowego rozwiązania. Brak dostępności na rynku istniejących dóbr

47 Szerzej na ten temat: H. Nowicki: Przygotowanie postępowania o udzielenie zamówienia publicznego i jego wpływ na innowacyjność udzielanego zamówienia [w:] H. Nowicki, P. Nowicki (red.), Państwo a gospodarka: kierunki zmian publicznym prawie gospodarczym, Toruń 2016. 
i rozwiązań mogących zaspokoić potrzeby zamawiającego jest niezbędną przesłanką zastosowania tej procedury ${ }^{48}$.

Procedura partnerstwa innowacyjnego jest szansą na realizację innowacyjnych projektów, które z założenia opierają się na współpracy sektora publicznego, prywatnego i instytucji naukowo-badawczych, gdyż umożliwia połączenia potencjałów trzech partnerów: świata nauki, sektora publicznego i prywatnego ${ }^{49}$.

Pkt 49 preambuły dyrektywy 2014/24/UE wskazuje, iż partnerstwo innowacyjne jest szczególną procedurą umożliwiająca zamawiającemu ustanowienie długotrwałej współpracy opartej na relacjach partnerskich, mającej na celu opracowanie, a następnie zakup nowego, innowacyjnego produktu, usługi lub roboty.

Jest to tryb, który zgodnie z art. 73a ust. 3 ustawy Prawo zamówień publicznych pozwala nabyć produkt innowacyjny, czyli nowy lub znacznie udoskonalony produkt, usługę lub proces, w tym proces produkcji, budowy lub konstrukcji, nową metodę marketingową lub nową metodę organizacyjną w działalności gospodarczej, organizowaniu pracy lub relacjach zewnętrznych ${ }^{50}$.

Zgodnie z treścią art. 37 ust. 3 ustawy Prawo zamówień publicznych zamawiający, prowadząc postępowanie o udzielenie zamówienia w trybie partnerstwa innowacyjnego, określając zapotrzebowania na innowacyjny produkt, usługę lub robotę budowlaną, wskazuje potrzeby i funkcjonalności, które ma spełniać przedmiot zamówienia, nie odnosząc się de facto do techniki lub sposobu realizacji przedmiotu zamówienia. Takie podejście pozwala na zaoferowanie przez zainteresowanego wykonawcę rozwiązania, która będzie zaspokajało potrzeby zamawiającego przy jednoczesnym

48 A. Sołtysińska, Komentarz do art. 31 dyrektywy 2014/24/UE w sprawie zamówień publicznych, uchylającej dyrektywę 2004/18/WE [w:] A. Sołtysińska, H. TalagoSławoj, Europejskie prawo zamówień publicznych. Komentarz, LEX, (dostęp: 15.12.2019 r.).

49 M. Borowiak, T. Siedlecki, Nowy tryb - partnerstwo innowacyjne, „Monitor Zamówień Publicznych” 2016, nr 9, s. 28-30.

50 Szerzej na ten temat: I. Skubiszak-Kalinowska, Innowacje w zamówieniach publicznych, „Temidium” 2010, nr 3, s. 36-42, oraz I. Skubiszak-Kalinowska, M. Kulesza, Innowacyjne zamówienia publiczne w Polsce-ekspertyza, Warszawa 2011, s. 9 i n. 
uzyskaniu istotnych dla instytucji publicznej efektów, np. oszczędności określonych w kryteriach oceny ofert.

Partnerstwo innowacyjne jest samodzielnym trybem udzielenia zamówienia publicznego, w którym wybór wykonawcy partnera opiera się w pewnej mierze na trybie negocjacji z ogłoszeniem. Procedura obejmie:

1. składanie wniosków o dopuszczenie do udziału w postępowaniu na podstawie treści ogłoszenia,

2. kwalifikację wykonawców do składania ofert wstępnych,

3. składanie ofert wstępnych,

4. negocjacje wykonawców z zamawiającym,

5. składanie ofert ostatecznych,

6. wybór najkorzystniejszej oferty.

Charakterystyczną cechą partnerstwa innowacyjnego jest jego etapowość, na którą składają się etapy odpowiadające kolejności działań w procesie badawczo-rozwojowym, w szczególności: prototypowanie oraz wytworzenie produktów, świadczenie usług lub ukończenie robót budowlanych. W ramach tej procedury zamawiający ustala cele pośrednie, które mają osiągnąć partnerzy, oraz przewiduje wynagrodzenie w częściach uwzględniających etapy partnerstwa lub cele pośrednie.

\section{Zamówienia w trybie podstawowym}

Zamówienia publiczne na innowacje mogą być poza partnerstwem innowacyjnym realizowane z zachowaniem podstawowych trybów określonych ustawą Prawo zamówień publicznych. Zgodnie z art. 29 ust. 4 ustawy Prawo zamówień publicznych zamawiający w opisie przedmiotu zamówienia może zawrzeć wymagania związane z innowacyjnością. Może również poprzez właściwe kształtowania kryteriów oceny ofert zmierzać do udzielenia zamówienia na innowacyjny przedmiot.

Zamawiający ma możliwość ogłosić postępowanie w jednym z trybów podstawowych, tj. przetargu nieograniczonego czy ograniczonego, jednak w przypadku zamówienia na innowacje pojawia się podstawowy problem dotyczący przygotowania opisu przedmiotu zamówienia. Rozwiązaniem może być dialog techniczny, który pozwoli ustalić faktyczne 
zapotrzebowanie na innowacje w danym obszarze. Dialog techniczny jest uregulowany w przepisach Prawa zamówień publicznych. Umożliwia on zamawiającym uzyskanie niezbędnej wiedzy na temat przedmiotu zamówienia, co w konsekwencji pozwala na ogłoszenie postępowania w jednym z wybranych trybów udzielania zamówień publicznych.

Zamawiający może udzielić zamówienia w trybach negocjacyjnych, procedurze dialogu konkurencyjnego czy konkursu, których charakter bardziej odpowiada specyfice zamówień innowacyjnych ${ }^{51}$.

Zamawiający, stosując podstawowe tryby udzielenia zamówienia, ma możliwość nabywania rozwiązań istniejących na rynku, charakteryzujących się innowacyjnymi rozwiązaniami, najnowszą technologią, jednakże niecechujących się powszechną dostępnością bądź też mających charakter niszowy, nierozpropagowanych do powszechnego użytkowania. Nie ma obowiązku stosowania w tym zakresie partnerstwa innowacyjnego i dążenia do poszukiwania rozwiązań, w których poprzez uczestniczenie na etapie prowadzenia badań i wdrożenia zrealizuje oczekiwane cele i rezultaty.

\section{Podsumowanie}

Sektor publiczny w Unii Europejskiej i na całym świecie zmaga się z ważnymi wyzwaniami społecznymi, które w swoim założeniu zmierzają między innymi do zwiększenia jakości i efektywności realizowanych zadań przy zachowaniu wysokości kosztów. Aby zrealizować te wymagania, niezbędne jest poszukiwanie nowych rozwiązań i technologii bądź też wykorzystywania istniejących rozwiązań, ale niedostępnych na szeroką skalę.

Stosowanie zamówień na innowacje stanowi jedno ze źródeł rozwoju przedsiębiorstw oferujących najnowsze rozwiązania techniczne i technologiczne, które z różnych względów, niekoniecznie wynikających z wysokiej ceny, nie weszły na rynek w szerokim zakresie.

51 Szerzej na ten temat: H. Nowicki, Prawo zamówień publicznych instrumentem kreowania innowacyjnej gospodarki [w:] A. Powałowski (red.), Prawne instrumenty oddziaływania na gospodarkę, Warszawa 2016, s. 295-297. 
Sektor publiczny w Stanach Zjednoczonych wydaje rocznie $50 \mathrm{mi}$ liardów dolarów na zamówienia badawczo-rozwojowe, co jest kwotą dwadzieścia razy większą niż w przypadku Europy i stanowi około połowę różnicy między Stanami Zjednoczonymi a Europą, jeżeli chodzi o łączne nakłady inwestycyjne w zakresie badań i rozwoju. Odgrywa to często znaczącą rolę w poprawie jakości usług publicznych oraz tworzeniu przedsiębiorstw konkurencyjnych w skali światowej ${ }^{52}$.

Działania UE, co zostało przedstawione, związane z promowaniem zamówień na innowacje, zwiększeniem ich znaczenia w systemie prawa, przejawiające się między innymi przyjęciem partnerstwa innowacyjnego, zmierzają do wzrostu zainteresowania innowacyjnymi rozwiązaniami przez zamawiających.

Istotną kwestią, jakiej nie można pominąć w prowadzonej analizie, są oczekiwania, jakie się stawia zamówieniom publicznym na innowacje. Sektor publiczny chce przez nie osiągnąć jednocześnie kilka istotnych efektów. Po pierwsze, nabycie innowacyjnych towarów, usług i robót budowlanych ma w jak największym zakresie, przy jednoczesnym wykazaniu korzyści ekonomicznej związanej z wydatkowanymi środkami publicznymi, zaspokoić ustalone i sprecyzowane potrzeby zamawiającego. Po wtóre, korzystanie z innowacji ma przynieść zwiększenie wydajności, efektywności, ale i jakości realizowanych przez jednostki publiczne na rzecz obywatela zadań. Korzystanie z innowacyjnych rozwiązań może mieć znamienny wpływ na wysokość wydatkowanych środków publicznych w określonej perspektywie czasowej w sytuacji korzystania przez zamawiającego z oceny kosztów cyklu życia. Po trzecie, zaangażowanie środków publicznych w rozwój innowacyjnych produktów i usług ma wzmocnić potencjał innowacyjny UE, która stawia sobie i państwom członkowskim to za cel strategiczny. Modernizacja gospodarki osiągana przez zamówienia na innowacje jest przejawem realizacji strategicznego celu wprowadzonej w życie w 2005 r. strategii lizbońska na rzecz wzrostu i zatrudnienia, która określa wszechstronny zestaw polityk i reform, któ-

52 US defence R\&D spending: an analysis of the impacts, raport EURAB, PREST, 2004. 
rych celem jest uczynienie europejskich ram prawnych i gospodarczych bardziej sprzyjającymi innowacyjności.

System prawa polskiego pozwala na przeprowadzeniu postępowania o udzielnie zamówienia publicznego, w efekcie którego nabywać będziemy innowacyjne towary, usługi bądź roboty budowlane. Zwiększenie świadomości zamawiających związane z potrzebą stosowania zamówień na innowacje, jak również rolą i efektami, jakie mogą one przynieść nie tylko jednostce sektora finansów publicznych, ale również społeczeństwu, wydaje się zadaniem z jakim powinien się zmierzyć Urząd Zamówień Publicznych.

\section{Bibliografia:}

Borowiec A., Zamówienia publiczne jako instrument kreowania popytu na innowacje, Wydawnictwo Politechniki Poznańskiej, Poznań 2013.

Borowski P.F., Przedsiębiorstwa XXI wieku, „Europejski Doradca Samorządowy” 2011, nr 2, s. 8-13.

Cieślak R., Przedkomercyjne zamówienia publiczne szansq na rozwój polskich regionów, „Gazeta Samorządu i Administracji” 2010, nr 13/14, www.gsia.infor.pl (dostęp: 10.12.2019 r.).

Gomes P.C., The innovative innovation partnerships under the 2014 Public Procurement Directive, "Public Procurement Law Review” 2014, nr 4, s. 211-221.

Kocowski T., Zorganizowanie uczestników procesu zamówień publicznych, a efektywność wykorzystania środków publicznych [w:] E. Adamowicz, J. Sadowy (red.), Zamówienia publiczne jako instrument sprawnego wykorzystania środków unijnych, Urząd Zamówień Publicznych, wyd. 2, Gdańsk-Warszawa 2012.

Niedzielski P., Rychlik K., Innowacje i kreatywność, Uniwersytet Szczeciński, Szczecin 2006.

Nowicki H., System zamówień publicznych jako regulacja prawna kreujq̨ca innowacyjność [w:] J. Niczyporuk, J. Sadowy, M. Urbanek (red.), Nowe podejście do zamówień publicznych - zamówienia publiczne jako instrument zwiększenia innowacyjności gospodarki i zrównoważonego rozwoju. Doświadczenia polskie i zagraniczne, Urząd Zamówień Publicznych, Warszawa 2011. 
Nowicki H., Innowacyjność w polskim prawie zamówień publicznych - zagadnienia wybrane [w:] A. Brzezińska-Rawa (red.), Rola państwa w procesach podnoszenia konkurencyjności i innowacyjności przedsiębiorstw. Diagnoza istniejqcych uwarunkowań i barier prawnych - perspektywy rozwoju, C.H. Beck, Warszawa 2015.

Nowicki H., Partnerstwo innowacyjne [w:] H. Nowicki, P. Nowicki (red.), Państwo a gospodarka: instrumenty prawne realizacji zamówień publicznych, Wydawnictwo KNPPG, Toruń 2016.

Nowicki H., Prawo zamówień publicznych instrumentem kreowania innowacyjnej gospodarki [w:] A. Powałowski (red.), Prawne instrumenty oddziaływania na gospodarkę, C.H. Beck, Warszawa 2016.

Nowicki H., Innowacyjność zamówień publicznych [w:] M. Stręciwilk, A. Dobaczewska (red.) Potrzeby i kierunki zmian w Prawie zamówień publicznych, Urząd Zamówień Publicznych, Warszawa 2018.

Olejarz M., Rola zrównoważonych zamówień publicznych i praktyka ich wykorzystania [w:] M. Stręciwilk, A. Panasiuk (red.), Funkcjonowanie systemu zamówień publicznych - aktualne problemy i propozycje rozwiqzzań, Urząd Zamówień Publicznych, Warszawa 2017.

Panasiuk A., Partnerstwo innowacyjne, „Państwo i Społeczeństwo” 2015, nr 1, s. $155-165$.

Panasiuk A., Rybak A., Zasada VfM w polskim systemie zamówień publicznych, „Studia Prawnicze i Administracyjne” 2017, nr 19 (1), s. 27-33.

Pożarowska J., Zamówienia publiczne na innowacje - $\operatorname{czy}(m)$ sq? [w:] M. Stręciwilk, A. Dobaczewska (red.), Potrzeby i kierunki zmian w Prawie zamówień publicznych, Urząd Zamówień Publicznych, Warszawa 2018.

Sadowy J, Cele systemu zamówień publicznych i ich realizacja na przestrzeni 15 lat $w$ świetle sprawozdań Prezesa Urzędu [w:] H. Nowicki, J. Sadowy (red.), XV-lecie systemu zamówień publicznych w Polsce, Urząd Zamówień Publicznych, Toruń-Warszawa 2009.

Sawin S., Bereszko W., Innowacyjne i przedkomercyjne zamówienia publiczne, Polska Agencja Rozwoju Przedsiębiorczości, Warszawa 2012.

Skubiszak-Kalinowska I., Innowacje w zamówieniach publicznych, „Temidium” 2010, nr 3, s. 36-42.

Skubiszak-Kalinowska I., Kulesza M., Innowacyjne zamówienia publiczne w Polsce - ekspertyza, Polska Agencja Rozwoju Przedsiębiorczości, Warszawa 2011. 
Sołtysińska A., Talago-Sławoj H., Europejskie prawo zamówień publicznych. Komentarz, Wolters Kluwer, Warszawa 2016.

Szostak R., Zamówienia publiczne instrumentem stymulacji rozwoju gospodarczego [w:] A. Powałowski (red.), Prawne instrumenty oddziaływania na gospodarkę, C.H. Beck, Warszawa 2016.

Szydło M., Prawna koncepcja zamówienia publicznego, C.H. Beck, Warszawa 2014.

Wieloński M., Europejskie prawo zamówień publicznych jako narzędzie polityki społeczno-gospodarczej Unii Europejskiej, Poltext, Warszawa 2014.

Wiktorowicz J., Bariery proinnowacyjnego oddziaływania zamówień publicznych z perspektywy innowacyjności i włq̨czenia MSP [w:] W. Starzyńska, J. Kornecki, J. Wiktorowicz, J. Szymański, Zamówienia publiczne a innowacyjność MŚP, Polska Agencja Rozwoju Przedsiębiorczości, Warszawa 2013.

Zastempowski M., Uwarunkowania budowy potencjału innowacyjnego polskich małych i średnich przedsiębiorstw, Wydawnictwo Naukowe UMK, Toruń 2010. 